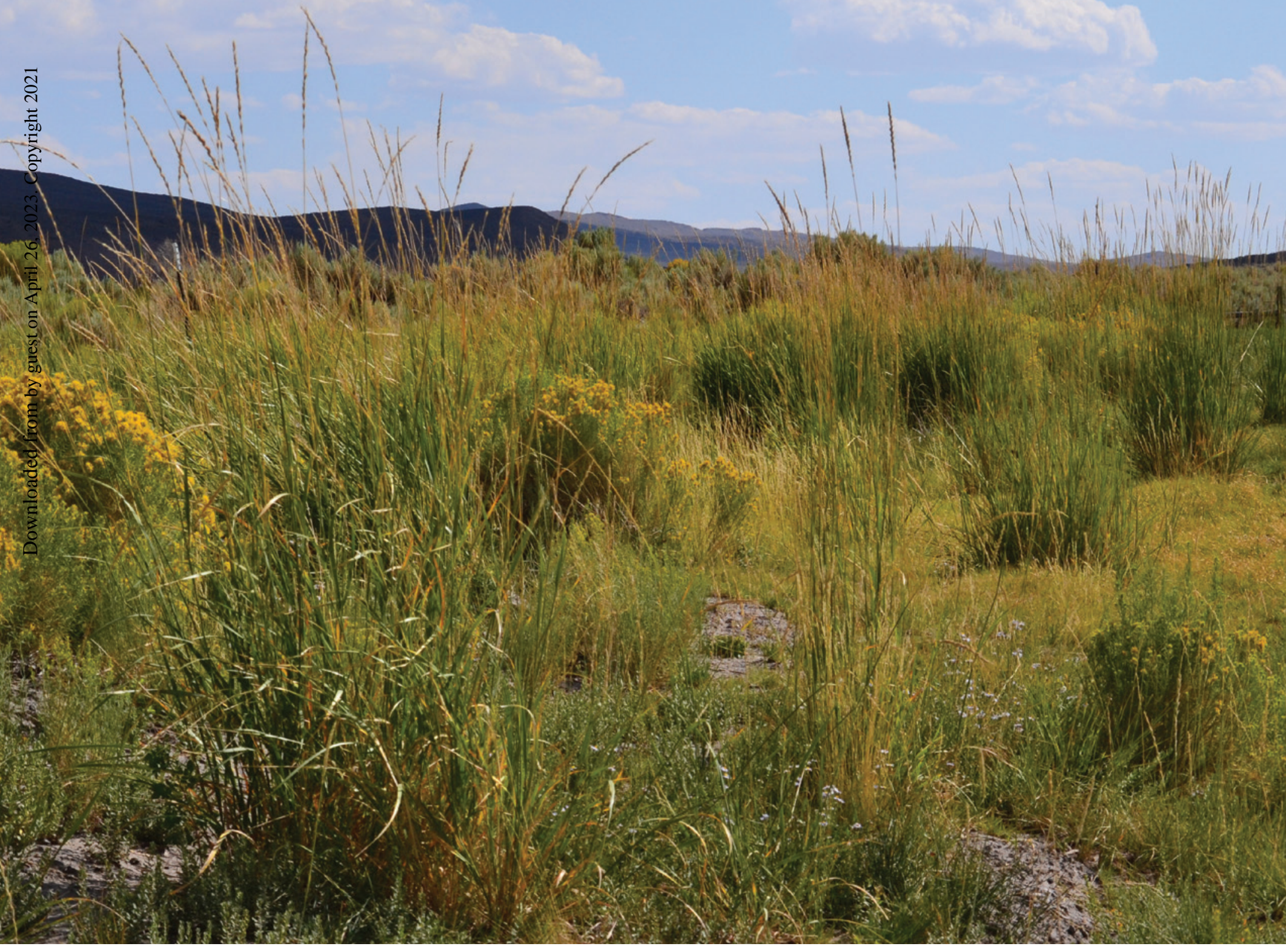

112 A typical wildland basin wildrye (Leymus cinereus) population. 


\title{
Does basin wildrye (Leymus cinereus) show local adaptation when deployed according to generalized provisional seed zones in the Central Basin and Range ecoregion?
}

\author{
Scott Jensen, Val Jo Anderson, William Christensen, Bruce Roundy, Stanley Kitchen, and Loreen Allphin
}

ABSTRACT

Identifying genetically appropriate plant materials for seed-based restoration relies on the principle of local adaptation: the intent to match adaptive genetic characteristics to variation in ecological clines pertinent to plant establishment and persistence. Seed zone maps delineate some of these relationships. Generalized provisional seed zones (GPSZ) were developed for use where species-specific seed zones are lacking, as was the case for basin wildrye at the initiation of this study. In this study, basin wildrye (Leymus cinereus (Scribn. \& Merr.) Á. Löve [Poaceae]) sources from 25 wild populations and 4 commercial varieties were planted at 4 test sites representing the species distribution across GPSZ in the central basin and range ecoregion. Sources were seeded separately into 5 blocks for each of 2 treatments and data were grouped by tetraploid or octoploid cytotype and local or non-local origin for comparison. Treatments included coverage with row cover or uncovered controls. We assessed initial and short-term survival. Plantings failed at 2 sites in both 2013 and 2014, with too few plants to quantify differences. At the remaining 2 sites we found no differences in initial survival or short-term persistence between pooled local sources compared to pooled non-local sources. Among commercial sources, the cultivar 'Magnar' initially outperformed local pooled materials at Fountain Green but not at Nephi. This difference was not evident 3 and 4 y later. Initial establishment under row cover was dramatically better than uncovered controls but persisted only through years 3 and 4 at the Fountain Green site.

Jensen S, Anderson VJ, Christensen W, Roundy B, Kitchen S, Allphin L. 2021. Does basin wildrye (Leymus cinereus) show local adaptation when deployed according to generalized provisional seed zones in the Central Basin and Range ecoregion? Native Plants Journal 22(2):112-122.

\section{KEY WORDS}

local adaptation, basin wildrye, Leymus cinereus, Great Basin, provisional seed zones, row cover, Poaceae

\section{NOMENCLATURE \\ USDA NRCS (2020)}

Photos by Scott Jensen

This article was prepared by a U.S. government employee as part of the employee's official duties and is in the public domain in the United States. This open access article is distributed under the terms of the CC-BY-NC-ND license (http://creativecommons.org/licenses/by-nc-nd/4.0) and is freely available online at: http://npj.uwpress.org. 
I $\mathrm{n}$ recent years, plant material programs and policies have emphasized the development and deployment of genetically appropriate native plant materials (Richards and Chambers 1996; Rogers and Montalvo 2004; Shaw and others 2008; Oldfield and Olwell 2015; Wood and others 2015). The foundation of genetic suitability is the principle of local adaptation with the intent of exploiting genetic variation to both preserve and capitalize on spatially diverse functional traits to improve restoration outcomes (Leimu and Fischer 2008). In application, using genetically appropriate plant materials requires a suitable pairing of restoration sites with seed sources, so that the developing plant community provides desired ecosystem services and persists through environmental challenges (Johnson and others 2010b; Jones 2013).

Genecological studies are a common first step in understanding morphological and phenological variation that can be used to identify adaptive genetic differences between populations (Campbell 1986; Erickson and others 2004; Johnson and others 2015). In genecological studies, numerous populations of the same species are planted in one or more common environments, and many traits that may have adaptive significance are evaluated. Resulting data, when paired with climate records from source population locations, are used to develop seed transfer guidelines, which are often displayed as seed zone maps. For a number of prominent Great Basin restoration grasses, genecological work is underway (Johnson and others 2010a; Johnson and others 2012; St Clair and others 2013; Johnson and others 2015) and was recently completed for basin wildrye (Leymus cinereus (Scribn. \& Merr.) Á. Löve [Poaceae]) (Johnson and Vance-Borland 2016). Yet, where genecological work is absent, many species will, of necessity, be planted without species-specific seed zone recommendations (Bower and others 2014). In these cases, surrogate approaches have been suggested (Omernik 1987; Milberg and Andersson 1998; Hargrove and Hoffman 2005; Vogel and others 2005; Johnson and others 2010b; Miller and others 2011; USDA 2013).

In this study, we evaluated a leading surrogate, generalized provisional seed zones (GPSZ) (Bower and others 2014; Kramer and others 2015), as a method of matching basin wildrye source populations to representative restoration sites. GPSZ delineate areas of similar winter minimum temperature and annual aridity, characteristics important to plant adaptation. When paired with ecoregions (Omernik 1987), they partition areas into climatically and ecologically distinct units and are recommended as a starting point for developing seed transfer guidelines.

Basin wildrye was selected as the test species because it is a common restoration species (Krabacker 2013) in the Intermountain region, yet its genecological seed zones had not been developed at the time this study was initiated. Its distribution extends from New Mexico to Saskatchewan and
Range (CBR) ecoregion, its known distribution ranges over $1100 \mathrm{~m}$ (3630 ft) in elevation and across 9, level 4 ecoregions (Omernik 1987). A substantial array of climatic and ecological variation occurs throughout this species distribution that may lead to the development of localized adaptions between spatially or ecologically divergent populations (Hereford 2009). Across the western portion of the species distribution, Culumber and others (2013) genetically distinguished 3 metapopulation races corresponding to the Columbia, Rocky Mountain, and Great Basin regions. Octoploid cytotypes were more abundant in the western portion of the species range, and tetraploid cytotypes were more abundant in the eastern portion. In the Great Basin, where the Great Basin race is fully encompassed by the more broadly distributed Rocky Mountain race, both cytotypes are common. In a recently completed common-garden study (Johnson and Vance-Borland 2016), genetic variation for both cytotypes was linked to source climates. That information was used to delineate 15 genecological seed zones for basin wildrye.

To test the principle of local adaptation, we hypothesized that wild basin wildrye sources planted into test sites matching their home GPSZ would demonstrate local adaptation through higher initial establishment and better short-term persistence. We also hypothesized local GPSZ pooled sources would similarly outperform the cultivars 'Magnar', 'Trailhead', and 'Continental', which originate from outside the Great Basin, and Great Basin 'Tetra', which is a composite of 31 sources from multiple GPSZ's and ecoregions. From experience using fabric row cover to improve seedling establishment in nursery beds, we included row cover as a treatment option in this experiment and hypothesized basin wildrye establishment would be better under row cover.

\section{METHODS}

Within the Great Basin, known populations of basin wildrye $(n=107)$ were mapped to 9 of the 20 Great Basin GPSZ's (WWETAC 2021) using ArcMap 10.1 (ESRI 2012). Five zones were poorly represented, containing 1 to 3 populations within their boundaries, while 4 zones accounted for the remaining $91.6 \%$ of populations. Bower and others (2014) demonstrated GPSZ's to be most effective when nested within Omernik's level III ecoregions. Consequently, for this study, source populations were restricted to origins within the CBR ecoregion. Basin wildrye population locations were obtained from a US Forest Service database developed over the course of several decades of plant material work and were originally located by travel throughout the area, consultation with federal and state agency personnel, or university and online herbarium sources.

Basin wildrye occurs in 2 cytotypes, tetraploid $(2 \mathrm{n}=28)$ and octoploid $(2 \mathrm{n}=56)$ (Ogle and others 2012). Crossing cytotypes results in sterile seed or unstable hexaploids (Young and others 
2013). Consequently, cytotypes should not be combined when assembling multi-origin seed sources for grow out or on restoration projects. As our interest, in this study, was to evaluate only establishment and short-term persistence, sources (Table 1) were not isolated by cytotype but data were grouped by cytotype for analysis.

In 2013, leaf tissue was collected from CBR populations and processed through a Partec flow cytometer to determine cytotype. Leaves were harvested, placed in resealable plastic bags, and kept on ice while in the field. Leaves were then transferred to a cooler $\left(3{ }^{\circ} \mathrm{C}\left[37.4^{\circ} \mathrm{F}\right]\right)$ until cytotype determination, following methods described by Richardson and others (2012).
Leaves from 2 plants per site were processed to determine each population's cytotype. Across the western portion of the species distribution, Culumber and others (2013) found no cases of mixed ploidy within populations of basin wildrye.

When developing genetically appropriate stock seed supplies, leading recommendations suggest pooling seed from at least 5 populations representing in aggregate more than 50 parents (Brown and Marshall 1995; Withrow-Robinson and Johnson 2006; Johnson and others 2010b). Basin wildrye populations were mapped according to seed zone and cytotype to identify populations for each zone/cytotype combination. For this study, we were not able to locate 5 populations for each

\section{TABLE 1}

Locations, cytotypes, and generalized provisional seed zone of basin wildrye populations and test sites used in this study.

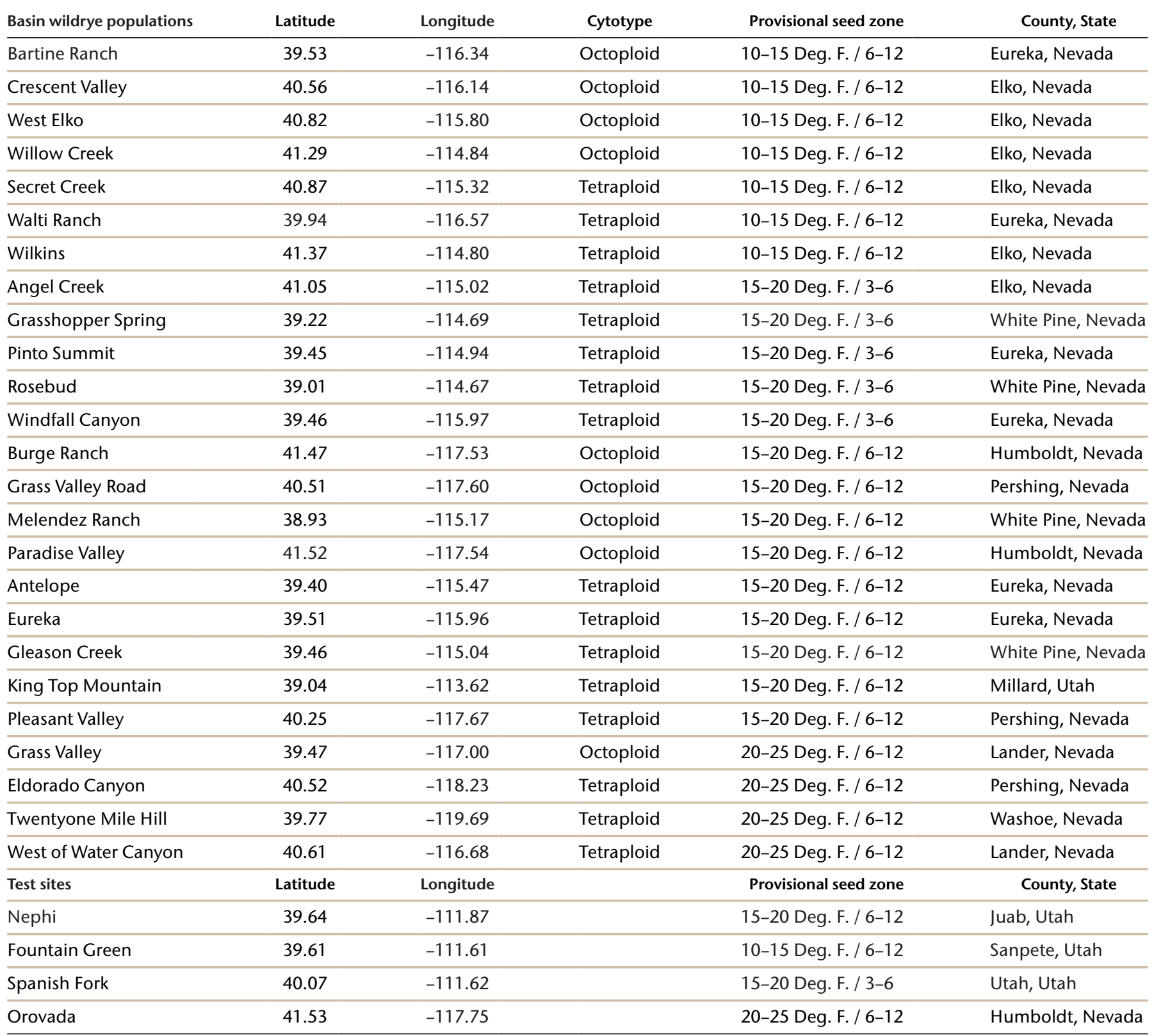


GPSZ/cytotype combinations (Table 2), nevertheless all had in excess of 100 parents.

Magnar, Trailhead, and other source-identified populations of basin wildrye have historically been seeded extensively in the Great Basin, especially following fire. To minimize the possibility of collecting planted sources of these materials, we excluded populations that occurred within evident fire perim- eters, adjacent to roadsides, and within boundaries of federal restoration projects (Pilliod and Welty 2013), and we visited with landowners or ranch managers about seeding history on private lands.

In 2013 and 2014, basin wildrye seed was harvested from a minimum of 50 individual plants at 25 wildland populations. Seed from each source was maintained separately, cleaned

\section{TABLE 2}

Local provisional seed zone for each test site along with the number of basin wildrye populations of each cytotype originating from that provisional seed zone and pooled for comparison. Also shown are the comparisons that were made to non-local sources and cytotypes.

\begin{tabular}{|c|c|c|c|c|c|c|c|c|c|c|c|}
\hline Site & Local source & $n$ & Cytotype & & & Non-I & cal sources & & & & \\
\hline \multirow{2}{*}{ Orovada } & \multirow{2}{*}{$\begin{array}{l}\text { 20-25 Deg. } \\
\text { F. / 6-12 }\end{array}$} & 3 & Tetraploid & & $\begin{array}{c}\text { 15-20 Deg. } \\
\text { F. / 6-12 }\end{array}$ & $\begin{array}{c}\text { 15-20 Deg. } \\
\text { F. / 3-6 }\end{array}$ & $\begin{array}{c}\text { 10-15 Deg. } \\
\text { F. / 6-12 }\end{array}$ & Tetra & & & Trail \\
\hline & & 2 & Octoploid & & $\begin{array}{l}\text { 15-20 Deg. } \\
\text { F. / 6-12 }\end{array}$ & & $\begin{array}{c}\text { 10-15 Deg. } \\
\text { F. / 6-12 }\end{array}$ & & Cont & Mag & \\
\hline Nephi & $\begin{array}{c}\text { 15-20 Deg. } \\
\text { F. / 6-12 }\end{array}$ & 3 & Tetraploid & $\begin{array}{c}20-25 \text { Deg. } \\
\text { F. / 6-12 }\end{array}$ & & $\begin{array}{c}\text { 15-20 Deg. } \\
\text { F. / 3-6 }\end{array}$ & $\begin{array}{c}\text { 10-15 Deg. } \\
\text { F. / 6-12 }\end{array}$ & Tetra & & & Trail \\
\hline \multirow[t]{2}{*}{ Spanish Fork } & \multirow{2}{*}{$\begin{array}{l}\text { 15-20 Deg. } \\
\text { F. / 3-6 }\end{array}$} & 5 & Tetraploid & $\begin{array}{c}20-25 \text { Deg. } \\
\text { F. / 6-12 }\end{array}$ & $\begin{array}{l}\text { 15-20 Deg. } \\
\text { F. / 6-12 }\end{array}$ & & $\begin{array}{c}\text { 10-15 Deg. } \\
\text { F. / 6-12 }\end{array}$ & Tetra & & & Trail \\
\hline & & 0 & Octoploid & & & & & & Cont & Mag & \\
\hline Fountain Green & $\begin{array}{c}\text { 10-15 Deg. } \\
\text { F. / 6-12 }\end{array}$ & 4 & Tetraploid & $\begin{array}{c}\text { 20-25 Deg. } \\
\text { F. / 6-12 }\end{array}$ & $\begin{array}{l}\text { 15-20 Deg. } \\
\text { F. / 6-12 }\end{array}$ & $\begin{array}{c}\text { 15-20 Deg. } \\
\text { F. / 3-6 }\end{array}$ & & Tetra & & & Trail \\
\hline
\end{tabular}

Notes: Shading indicates data were not available at these sites due to seeding failures. Tetra = Great Basin Tetra; Cont $=$ Continental; Mag = Magnar; Trail $=$ Trailhead.

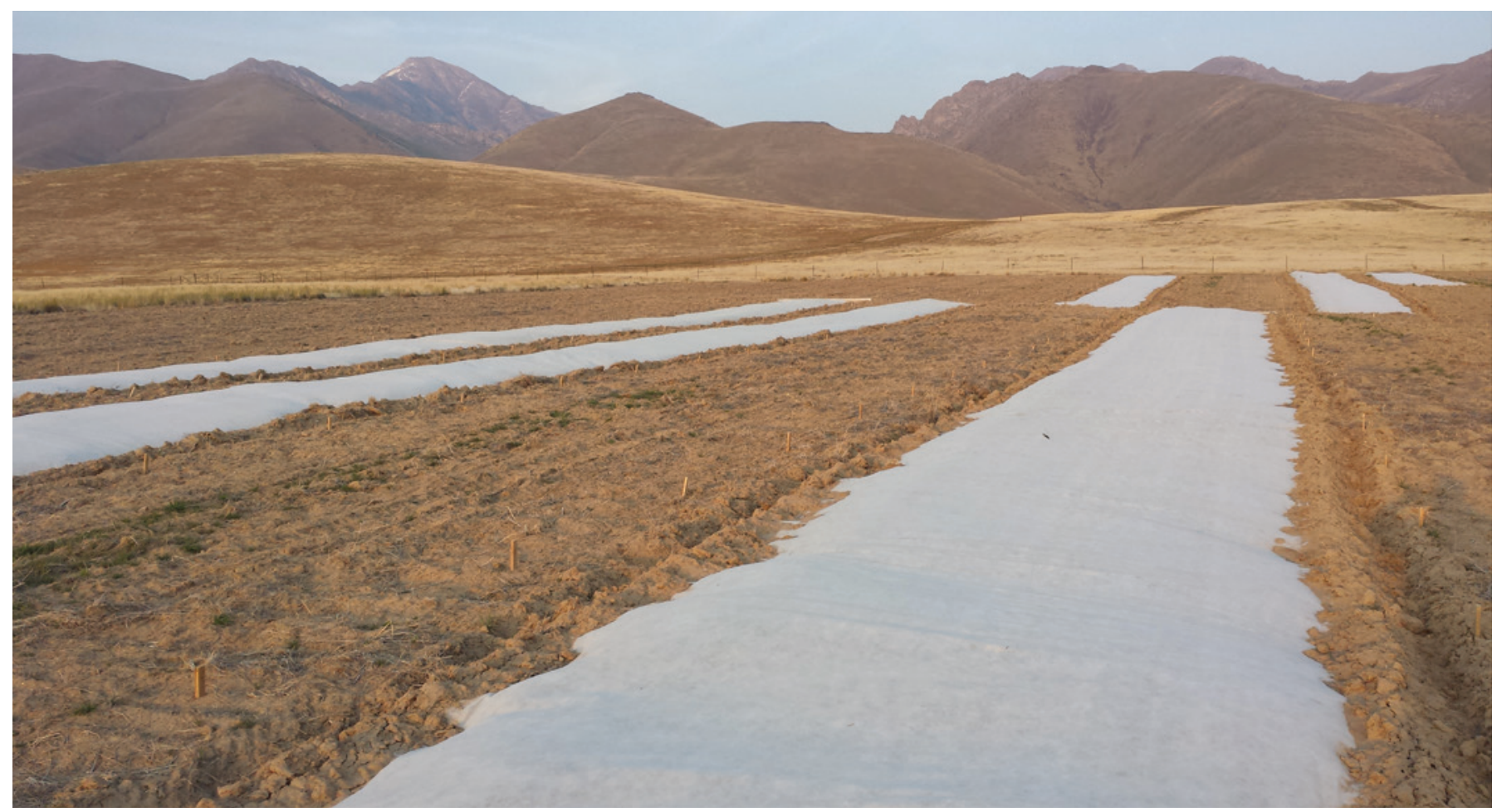

Orovada, Nevada, test plot planted and covered with row cover fabric. 
using a Clipper laboratory seed cleaner and Carter Day fractionating aspirator, and viability tested (TZ) at the Utah State Seed Laboratory. Commercial certified basin wildrye sources, Magnar, Trailhead, and Tetra, were acquired from the Utah Division of Wildlife Resources, Great Basin Research Center, seed warehouse.

\section{Test Sites}

Test sites were located in each of the 4 GPSZ's with basin wildrye population occurrence rate more than 5\%. The Spanish Fork, Utah, location represented zone 15-20 Deg. F. / 3-6 and occurred on a Timpanogos loam soil type (Farmlogs 2018a). Annual precipitation averaged $43 \mathrm{~cm}$ (17 in) over the past $10 \mathrm{y}$ (Farmlogs 2018b). The Nephi, Utah, location represented zone 15-20 Deg. F. / 6-12 and occurred on Nephi silt loam soil. It averaged $28 \mathrm{~cm}$ (11 in) of precipitation. The Orovada, Nevada, location represented zone 20-25 Deg. F. / 6-12 and occurred on the Snapp-McConnel-Adeliade soil association. It averaged $16.5 \mathrm{~cm}$ (6.5 in) of annual precipitation. The Fountain Green, Utah, location represented the 10-15 Deg. F. / 6-12 GPSZ. Soils were classified as a Keigley silty clay loam (Farmlogs 2018a), and annual precipitation averaged $33 \mathrm{~cm}$ (13 in) over the past 10 y (Farmlogs 2018b).

In May of 2013 and 2014, plots at each site were disked to incorporate existing vegetation and summer fallowed. In early fall, the sites were harrowed and roller packed to prepare the seedbed for planting. Several weeks prior to planting, plots were treated with the nonselective herbicide glyphosate to remove fall-germinated seedlings. Glyphosate was chosen for its ability to control a broad spectrum of grasses and broadleaf plants while also strongly binding to soil particles, rendering it biologically unavailable with no soil residual activity (Monsanto 2004). Planting occurred during the first half of November in both years. In 2014, plots were mowed in May at a $10 \mathrm{~cm}$ (4 in) stubble height to limit weed seed maturation. Plots were not mowed in 2015.

\section{Row Cover Treatment}

DeWitt's $51 \mathrm{~g} / \mathrm{m}^{2}\left(1.5 \mathrm{oz} / \mathrm{yd}^{2}\right)$ N-Sulate (DeWitt Company, Sikeston, Missouri) is a medium weight, permeable, UV-treated fabric designed to offer frost protection to plants, reduce evaporation rate, lengthen harvest time, and/or extend flowering season. Studies report 3 to $5{ }^{\circ} \mathrm{C}$ higher soil temperatures under row cover (Harris and others 2015) and up to $6 \%$ more moisture (Tilley and others 2009) compared to uncovered soils. Other studies report increased survival of spring emerging seedlings (Tilley and others 2009; Stettler and Whitaker 2012; Shock and others 2013) as well as overwintering perennial plants (Harris and others 2015). Following seeding, beds were enclosed with $3.6 \mathrm{~m}$ (12 ft) wide row cover using a tractor-drawn plastic mulch layer. The cover remained in place through early spring.

\section{Study Design}

A primary objective of this study was to compare establishment success among populations seeded in a manner similar to a restoration planting. This approach differs from most reciprocal studies, which are established using outplanted nurserygrown stock. Outplants, particularly suitable from a research design perspective, permit evaluation of mature plant performance and longevity, but bypasses the seedling life phase. Establishing the study by direct seeding permits evaluation of this critical establishment phase, upon which all subsequent performance and longevity data rely.

The study was implemented as a 2-factor factorial that included row cover treatment and seed source in a split plot design. We assigned 10 whole plots (blocks) for treatments of row cover ( $n=5$ blocks) or uncovered controls ( $n=5$ blocks), and seed sources were randomly assigned in subplots. In 2013 and 2014 , at each site, each of 29 seed sources was planted at a density of 68.3 pure live seeds (PLS) per m (20.83 PLS/ft) along a $1.8 \mathrm{~m}$ (6 ft) row length. Seed was sown $2 \mathrm{~cm}$ (0.8 in) deep with a tractor-drawn custom Hege 1000 series cone seeder, planting through John Deere double disc openers.

\section{Data Collection and Analysis}

Year 1 establishment data, recorded as the total number of individual plants occurring in each row, were collected in the fall of each year following seeding. Short-term persistence data (year 3-4), measured as linear centimeters of row occupied by basin wildrye, were recorded in fall 2017, 4 y post-2013 planting and 3 y post-2014 planting. Sources were classified as local if they originated in the same GSPZ as the test site. For analysis, data from individual sources were either evaluated separately or pooled by cytotype or originating GPSZ to address hypotheses of interest. For example, when evaluating establishment differences at Fountain Green between local (10-15 Deg. F. I 6-12) octoploids and non-local (15-20 Deg. F. / 6-12) octoploids, data from 5 populations were grouped to create the local octoploid data set, and data from 3 populations were grouped to create the non-local octoploid data set. Tetraploid and octoploid groupings were analyzed separately because of the genetic constraints of mixing these cytotypes. Data were analyzed using SAS Mixed Procedure (SAS Institute 2004) as a split plot, with cover treatments as whole plots and sources as subplots. Site, year, cover treatment, and source were considered fixed effects whereas block was considered a random effect.

Precipitation data were assembled from Farmlogs by delineating study sites and using the built-in rainfall feature. Farmlogs report National Oceanic and Atmospheric Administration (NOAA) data, which are calculated using radar and ground stations to algorithmically predict the amount of precipitation that falls on a high-resolution $(1 \mathrm{~km}$ [0.6 mi]) grid of the US. 


\section{Year 1 Establishment}

At both the Orovada and Spanish Fork sites in 2013 and 2014, spring seedling emergence was very poor and subsequent mortality was high. By fall, when year 1 data were recorded, too few plants remained to make valid statistical inferences. For the remaining sites, we compared year 1 survival between pooled local GPSZ sources (occurring within the same GSPZ as the test site) and non-local (originating from other GPSZ) tetraploid sources, pooled local and nonlocal octoploid sources, and local tetraploid groups or local octoploid groups versus commercial sources (see Table 2). At Fountain Green, significant differences were observed between sources, treatments, year, and the interaction treatment $\times$ year (Table 3 ). Magnar established better than pooled local octoploids and pooled local tetraploids (Table 4). No differences occurred between local and non-local pooled GPSZ sources or pooled local GPSZ sources and other commercial sources. Survival in row cover treatments was better in 2014 than 2013 (Table 5), and survival in row cover treatments was better both years than survival in control plantings in 2014 and 2013, which also differed from each other. Contrasting with row cover treatments, survival in control was higher in 2013 than 2014 causing the significant treatment $\times$ year interaction (Tables 3 and 5).
For year 1 survival at Nephi, significant differences were observed between treatment, year, and the interaction treatment $\times$ year (Table 3 ). No detectable differences occurred between sources. Similar to the Fountain Green site, survival in row cover treatments was better in 2014 than 2013, and survival in row cover treatments was better both years than survival in control plantings, which did not differ by year (Table 5). Contrasting with row cover treatments, survival in control was greater, though not significantly so, in 2013 than in 2014 (Table 5), causing the significant treatment $\times$ year interaction (Table 3).

\section{Short-Term Persistence}

At Fountain Green there were no differences among sources in short-term persistence (year 3-4), measured as linear centimeters of row occupied by basin wildrye (Table 3). We observed significant differences in short-term persistence between treatment, year, and the treatment $\times$ year interaction (Table 3). Short-term persistence was higher in row cover than in control plots both years. Short-term persistence was higher in 2013 than in 2014 row cover plots. Control plots were similar between years. In contrast to row cover treatments, survival in control was greater in 2014 than in 2013, though not significantly so, causing the significant treatment $\times$ year interaction (Table 5). At Nephi, differences were observed only between

TABLE 3

Values (F and P) for testing overall effects of year 1 establishment for basin wildrye populations.

\begin{tabular}{|c|c|c|c|c|c|}
\hline \multirow[b]{2}{*}{ Site } & \multirow[b]{2}{*}{ Effect } & \multicolumn{2}{|c|}{ Year 1 establishment } & \multicolumn{2}{|c|}{ Short-term persistence } \\
\hline & & F statistic & $P$ value & F statistic & $P$ value \\
\hline \multicolumn{6}{|c|}{ Fountain Green } \\
\hline & Source & 1.76 & 0.0104 & 0.918 & 0.5885 \\
\hline & Treatment & 372.86 & $<.0001$ & 56.871 & $<.0001$ \\
\hline & Source $\times$ Treatment & 1.21 & 0.2103 & 4.011 & 0.9798 \\
\hline & Year & 11.08 & 0.0009 & 0.525 & 0.0458 \\
\hline & Source $\times$ Year & 1.15 & 0.2730 & 0.480 & 0.9898 \\
\hline & Treatment $\times$ Year & 26.14 & $<.0001$ & 5.867 & 0.0158 \\
\hline & Source $\times$ Treatment $\times$ Year & 0.98 & 0.4980 & 0.408 & 0.9973 \\
\hline \multicolumn{6}{|l|}{ Nephi } \\
\hline & Source & 1.19 & 0.2376 & 0.283 & 1 \\
\hline & Treatment & 422.12 & $<.0001$ & 2.332 & 0.127 \\
\hline & Source $\times$ Treatment & 1.16 & 0.2665 & 92.717 & 0.999 \\
\hline & Year & 227.62 & $<.0001$ & 0.354 & $<.0001$ \\
\hline & Source $\times$ Year & 0.7 & 0.872 & 0.247 & 1 \\
\hline & Treatment $\times$ Year & 238.17 & $<.0001$ & 0.004 & 0.948 \\
\hline & Source $\times$ Treatment $\times$ Year & 0.76 & 0.8106 & 0.242 & 1 \\
\hline
\end{tabular}


Values (t and P) for testing source effects on year 1 establishment of basin wildrye populations.

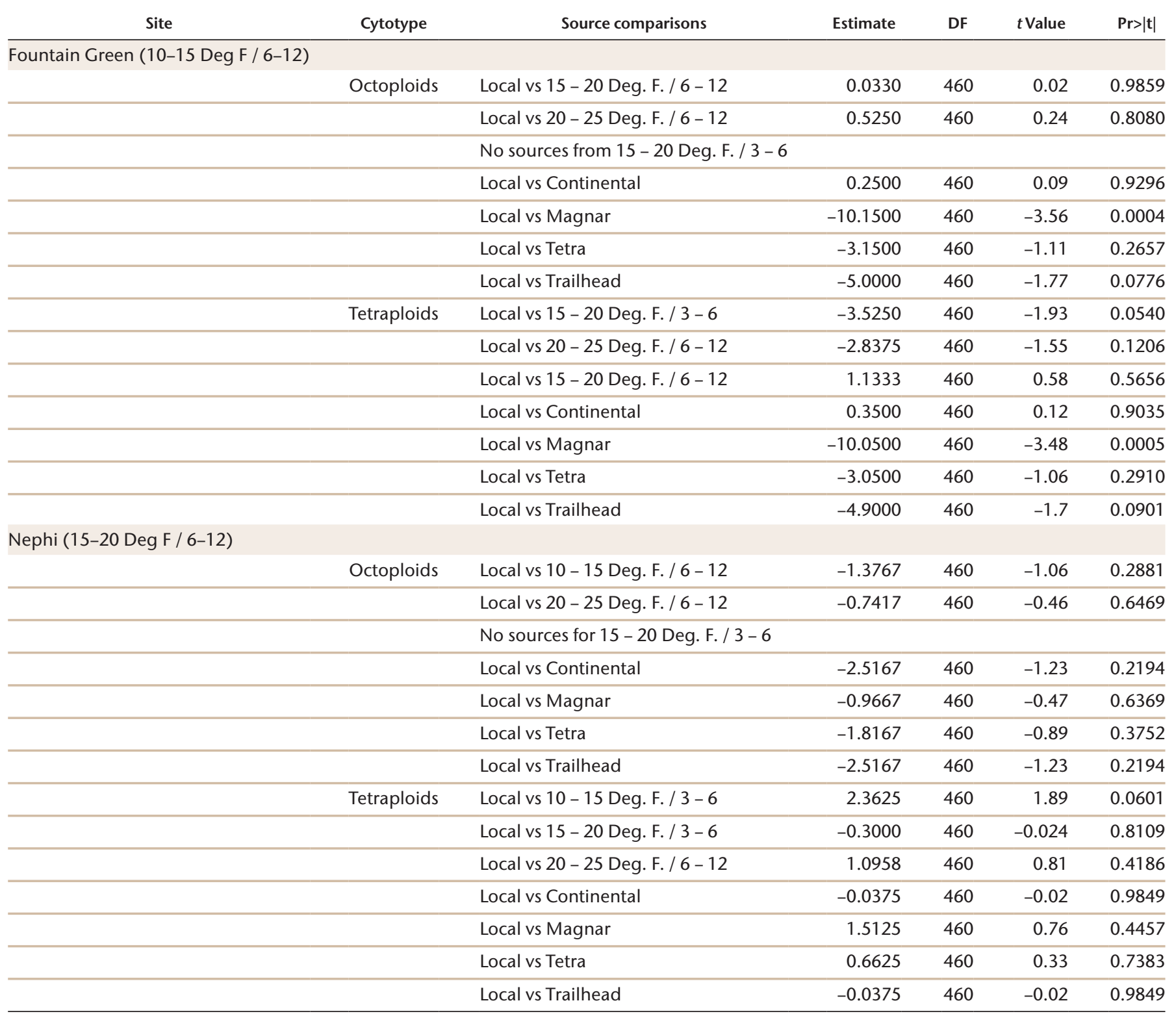

years (Table 3), with short-term persistence better in 2014 than in 2013 for both treatments (Table 5).

\section{DISCUSSION}

Unfortunately, failed plantings at Orovada and Spanish Fork reduced the scope of inference to half of what was intended. The ultimate cause of failure is unknown, although observed emergence was minimal at these sites. We speculate seed may have germinated during fall or winter months and perished from desiccation or frost (Roundy and Madsen 2016), or competition from weedy species may have suppressed emergence (Thomson and others 2017). Basin wildrye is a poor competi- tor during establishment when growing with competitive species (Ogle and others 2012), and at both the Orovada and the Spanish Fork sites, even following efforts to reduce the seedbank, considerable competition occurred from weedy species. Both locations appear suitable to support this grass: Remnant native stands persist adjacent to the Orovada test site on similar soil and topography and a planted field of basin wildrye persists near the Spanish Fork plot on similar soils. With these sites failing to contribute data to the objective, their singular contribution is merely to provide further observation that basin wildrye is a poor competitor during establishment.

A primary objective of this study was to test whether GPSZs geographically represent relevant partitions of selective gradi- 


\section{TABLE 5}

Values (t and P) for testing Treatment $\times$ Year effects on year 1 establishment and year 3-4 persistence of basin wildrye populations.

\begin{tabular}{|c|c|c|c|c|}
\hline \multirow{2}{*}{$\begin{array}{l}\text { Site } \\
\text { Fountain Green }\end{array}$} & \multicolumn{2}{|c|}{$\begin{array}{c}\text { Treatment } \times \\
\text { Year effect }\end{array}$} & Estimate & \multirow[t]{2}{*}{$\operatorname{Pr}>|t|$} \\
\hline & & & & \\
\hline \multicolumn{5}{|c|}{ Year 1} \\
\hline & Row cover & 2013 & $17.7034 \mathrm{~B}^{2}$ & $<.0001$ \\
\hline & Row cover & 2014 & $25.7931 \mathrm{~A}$ & $<.0001$ \\
\hline & Control & 2013 & $4.0966 \mathrm{C}$ & 0.0149 \\
\hline & Control & 2014 & $2.3862 \mathrm{D}$ & 0.1551 \\
\hline \multicolumn{5}{|c|}{ Year 3-4 } \\
\hline & Row cover & 2013 & $91.1862 \mathrm{~A}$ & $<.0001$ \\
\hline & Row cover & 2014 & 69.8689 B & 0.0012 \\
\hline & Control & 2013 & $43.1862 \mathrm{C}$ & 0.3692 \\
\hline & Control & 2014 & $45.2068 \mathrm{C}$ & 0.7385 \\
\hline \multicolumn{5}{|c|}{ Nephi } \\
\hline \multicolumn{5}{|c|}{ Year 1} \\
\hline & Row cover & 2013 & $4.5931 \mathrm{~B}$ & $<.0001$ \\
\hline & Row cover & 2014 & $24.6828 \mathrm{~A}$ & $<.0001$ \\
\hline & Control & 2013 & $1.2276 \mathrm{C}$ & 0.1058 \\
\hline & Control & 2014 & $1.0000 \mathrm{C}$ & 0.1875 \\
\hline \multicolumn{5}{|c|}{ Year 3-4 } \\
\hline & Row cover & 2013 & 20.1793 В & 0.0138 \\
\hline & Row cover & 2014 & $61.1862 \mathrm{~A}$ & $<.0001$ \\
\hline & Control & 2013 & 13.3517 B & 0.0277 \\
\hline & Control & 2014 & $54.9172 \mathrm{~A}$ & $<.0001$ \\
\hline
\end{tabular}

zLetters indicate significant differences within sites. ents under which basin wildrye has evolved, and thereby aptly partition populations into adaptive groups. We hypothesized local adaptation expressed by pooled local sources would perform better initially and over time than pooled non-local sources. Additional objectives were to compare local pooled GPSZ sources to the commercially available sources Trailhead, Magnar, Continental, and Great Basin Tetra and to evaluate row cover as a method to improve seedling establishment.

We expected local adaptation would first be expressed by differential establishment rates with local climate benefiting local sources. But, we observed no differences between local and non-local sources, grouped by cytotype and pooled by GPSZ, either initially or 3 to 4 y later. To ensure results from pooled sources were not obscured by poor performing individual sources, we compared pooled local GPSZ sources to local individual sources and again found no source differences. In other words, local individual sources performed similarly to local pooled sources at these 2 sites. Commercial sources, excepting Magnar, also failed to distinguish themselves. Magnar initially established better than local sources at Fountain Green but that difference was no longer evident by year 3-4. The intent of seed zones is to match seed sources to geographic areas where they are well adapted. Over the brief duration of this study, the lack of differences suggests basin wildrye functioned as a habitat generalist, unresponsive to seed zones. Selective gradients, if present or expressed during the study interval, did not exert persistent differential results. It is likely that documenting such selectivity may require more annual replication and longer persistence intervals to capture climatic variability sufficient to cause selective pressure. For basin wildrye, empirical seed zones are now available (Johnson and Vance-Borland 2016)

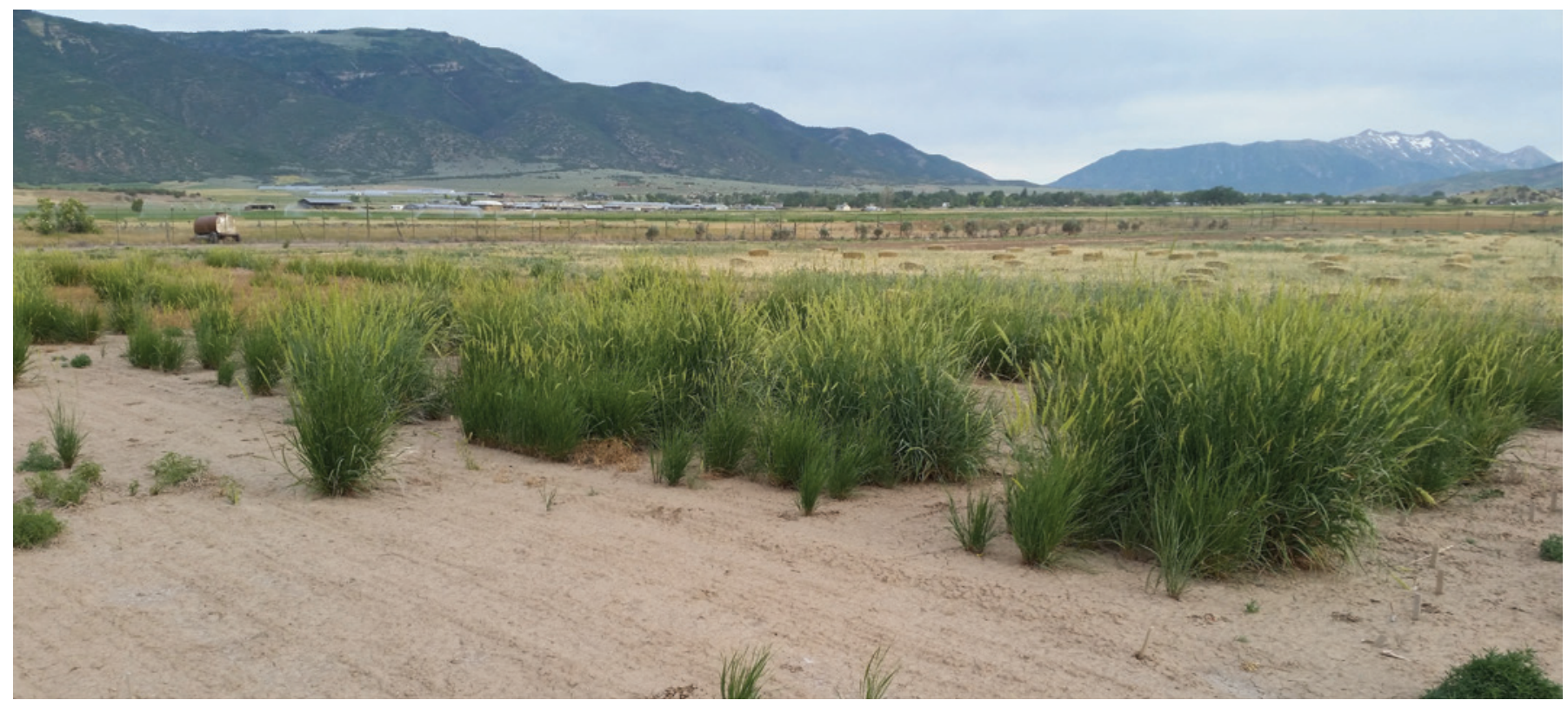


and are the best available tool to guide source development and deployment.

Row cover treatments dramatically improved year 1 establishment as compared to control treatments. The most modest improvement was 318\% at Nephi in 2013 (see Table 5). Good germination was observed in both row cover and control plots; however, the combined benefits of row cover, frost protection, warmer temperatures, and prolonged moisture availability dramatically benefited seedling establishment. These positive benefits are similar to others' findings (Tilley and others 2009; Stettler and Whitaker 2012; Shock and others 2013). At Fountain Green, beneficial effects remained through year 3-4, whereas at Nephi they were no longer statistically better. Using row cover to improve establishment may be suitable for some projects.

\section{ACKNOWLEDGMENTS}

This work was supported by the Great Basin Native Plant Project through the Department of the Interior/Bureau of Land Management Great Basin Restoration Initiative and the USDA Forest Service Rocky Mountain Research Station. Mention of a proprietary product does not constitute a guarantee or warranty of the product by USDA or the authors and does not imply its approval to the exclusion of other products that may also be suitable.

\section{REFERENCES}

Bower AD, St Clair B, Erickson V. 2014. Generalized provisional seed zones for native plants. Ecological Applications 24(5):913-919.

Brown AHD, Marshall DR. 1995. A basic sampling strategy: theory and practice. In: Guarino L, Rao VR, Reid R, Eatwell K, Goodman G, Keeble E, Meredith A, Heldey J, editors. Collecting plant genetic diversity: technical guidelines. Egham, UK: CABI. p 75-91.

Campbell RK. 1986. Mapped genetic-variation of Douglas-fir to guide seed transfer in southwest Oregon. Silvae Genetica 35:85-96.

Culumber CM, Larson SR, Jones TA, Jensen KB. 2013. Wide-scale population sampling identifies three phylogeographic races of basin wildrye and low-level genetic admixture with creeping wildrye. Crop Science 53(3):996-1007. doi:10.2135/cropsci2012.06.0396

Erickson VJ, Mandel NL, Sorensen FC. 2004. Landscape patterns of phenotypic variation and population structuring in a selfing grass, Elymus glaucus (blue wildrye). Canadian Journal of Botany-Revue Canadienne De Botanique 82:1776-1789.

[ESRI] Environmental Systems Research Institute. 2012. ArcGIS Release 10.1. Redlands (CA).

Farmlogs. 2018a. URL: https://farmlogs.com/farm-managementfeatures/\#soil-maps (accessed 16 Jan 2018).

Farmlogs. 2018b. URL: https://app.farmlogs.com/\#fields/rainfall (accessed 16 Jan 2018).

Hargrove WW, Hoffman FM. 2005. Potential of multivariate quantitative methods for delineation and visualization of ecoregions. Environmental Management 34(1 SUPPL):39-60. doi:10.1007/s00267003-1084-0
Harris WK, Latimer JG, Freeborn JF, Aiken M, Scoggins HL. 2015. Overwintering survival and vigor of container-grown fountain grass: influence of substrate moisture content, protective covers, and fertilizer rate. HortTechnology 25:791-795.

Hereford J. 2009. A quantitative survey of local adaptation and fitness trade-offs. American Naturalist 173(5):579-88. doi:10.1086/597611

Johnson RC, Vance-Borland K. 2016. Linking genetic variation in adaptive plant traits to climate in tetraploid and octoploid basin wildrye [Leymus cinereus (Scribn. \& Merr.) A. Love] in the western U.S. PLoS ONE 11(2):e0148982. doi:10.1371/journal.pone.0148982

Johnson RC, Erickson VJ, Mandel NL, St Clair JB, Vance-Borland KW. 2010a. Mapping genetic variation and seed zones for Bromus carinatus in the Blue Mountains of eastern Oregon, USA. BotanyBotanique 88:725-736. doi:10.1139/b10-047

Johnson RC, Stritch L, Olwell P, Lambert S, Horning ME, Cronn R. $2010 \mathrm{~b}$. What are the best seed sources for ecosystem restoration on BLM and USFS lands? Native Plants Journal 11(2):117-131. doi:10.2979/NPJ.2010.11.2.117

Johnson RC, Cashman MJ, Vance-Borland K. 2012. Genecology and seed zones for Indian ricegrass collected in the southwestern United States. Rangeland Ecology \& Management 65(5):523-532. doi:10.2111/REM-D-11-00165.1

Johnson RC, Horning ME, Espeland EK, Vance-Borland K. 2015. Relating adaptive genetic traits to climate for Sandberg bluegrass from the Intermountain western United States. Evolutionary Applications 8:172-184. doi:10.1111/eva.12240

Jones T. 2013. Ecologically appropriate plant materials for restoration applications. BioScience 63(3):211-219. doi:10.1525/ bio.2013.63.3.9

Krabacker P. 2013. Personal communication. Bureau of Land Management. Boise (ID). National Seed Coordinator.

Kramer AT, Larkin DJ, Fant JB. 2015. Assessing potential seed transfer zones for five forb species from the Great Basin floristic region, USA. Natural Areas Journal 35:174-188. Retrieved from Web of Science accession number WOS:000351425000019

Leimu R, Fischer M. 2008. A meta-analysis of local adaptation in plants. PLOS ONE 3(12):1-8. doi:10.1371/journal.pone.0004010

Milberg P, Andersson L. 1998. Does cold stratification level out differences in seed germinability between populations? Plant Ecology 134(2):225-234. doi:10.1023/A:1009793119466

Miller SA, Bartow A, Gisler M, Ward K, Young AS, Kaye TN. 2011. Can an ecoregion serve as a seed transfer zone? Evidence from a common garden study with five native species. Restoration Ecology 19(201):268-276. doi:10.1111/j.1526-100X.2010.00702.x

Monsanto. 2004. Roundup Original specimen label.

Ogle DG, Tilley D, St John L. 2012. Plant guide for basin wildrye (Leymus cinereus). Aberdeen (ID): USDA Natural Resources Conservation Service, Aberdeen Plant Materials Center.

Oldfield S, Olwell P. 2015. The right seed in the right place at the right time. Bioscience 65(10):955-956. doi:10.1093/biosci/biv127

Omernik JM. 1987. Ecoregions of the conterminous United States. Annals of the Association of American Geographers 77(1):118-125. doi:10.1111/j.1467-8306.1987.tb00149.x

Pilliod DS, Welty JL. 2013. Land Treatment Digital Library: U.S. Geological Survey Data Series 806. URL: http://pubs.er.usgs.gov/ publication/ds806 (accessed 2013).

Richards RT, Chambers JC. 1996. Use of native plants on federal lands. Policy and Practice 51(November):625-632.

Richardson BA, Page JT, Bajgain P, Sanderson SC, Udall JA. 2012. Deep sequencing of amplicons reveals widespread intraspecific hybridization and multiple origins of polyploidy in big sagebrush 
(Artemisia tridentata; Asteraceae). American Journal of Botany 99(12):1962-75. doi:10.3732/ajb.1200373

Rogers DL, Mantalvo AM. 2004. Genetically appropriate choices for plant materials to maintain biological diversity. University of California. Report to the USDA Forest Service, Rocky Mountain Region, Lakewood, Colorado. Genetic considerations in ecological restoration. p 1-333.

Roundy BA, Madsen MD. 2016. Frost dynamics of sagebrush steppe soils. Soil Science Society of America Journal 80:1403-1410.

SAS Institute Inc. 2002-2004. SAS 9.1.3 Help and documentation. Cary (NC): SAS Institute Inc.

Shaw NL, Pellant M, Olwell P, Jensen SL, McArthur ED. 2008. Native plant development and restoration program for the Great Basin, USA. In: Multifunctional grasslands in a changing world, Volume II; XXI International Grassland Congress; VIII International Rangeland Congress. Beijing, China: Guangdong People's Publishing House. 454 p.

Shock C, Feibert E, Saunders L, Shaw N. 2013. Direct surface seeding systems for successful establishment of native wildflowers. Corvallis (OR): Oregon State University, Malheur Experiment Station. Ext/ CrS 149:159-165.

St Clair B, Kilkenny FF, Johnson RC, Shaw NL, Weaver G. 2013. Genetic variation in adaptive traits and seed transfer zones for Pseudoroegneria spicata (bluebunch wheatgrass) in the northwestern United States. Evolutionary Applications 6(6):933-948. doi:10.1111/ eva.12077

Stettler JA, Whitaker A. 2012. Progress report. URL: https://www.fs.fed. us/rm/boise/research/shrub/projects/documents/2011_Progress Report.pdf.

Thomson DM, King RA, Schultz EL. 2017. Between invaders and a risky place: exotic grasses alter demographic tradeoffs of native forb germination timing. Ecosphere 8(10):e01987.10.1002/ecs2.1987

Tilley DJ, Frommelt D, Meyer D, Smith C, Young-Mathews A. 2009. Floating row cover improves in-field germination of broadcast seeded clustered field sedge (Carex praegracilis W. Boott). Final report. USDA Natural Resources Conservation Service. Lockeford (CA): Lockeford Plant Materials Center. 12 p.

[USDA] US Department of Agriculture. 2013. USDA plant hardiness zone map. Washington (DC). doi:10.5962/bhl.title.67926

[USDA NRCS] USDA Natural Resources Conservation Service. 2021. The PLANTS database. URL: http://plants.sc.usda.egov/home (accessed 1 Jan 2021). Greensboro (NC): National Plant Data Team.

Vogel KP, Schmer MR, Mitchell RB. 2005. Plant adaptation regions: ecological and climatic classification of plant materials. Rangeland Ecology \& Management 58(3):315-319. doi:10.2111/15515028(2005)58[315:PAREAC]2.0.CO;2

Withrow-Robinson B, Johnson R. 2006. Selecting native plant materials for restoration projects: ensuring local adaptation and maintaining genetic diversity. Forestry (November). $10 \mathrm{p}$.

Wood T, Doherty E, Padgett W. 2015. Colorado Plateau ecosystems development of native plant materials for restoration and rehabilitation of Colorado plateau ecosystems. BioOne 35(1):134-150. doi:10.3375/043.035.0117
[WWETAC] USDA Western Wildland Environmental Threat Assessment Center. 2021. Edited provisional seed zones for the Great Basin. URL: https://www.fs.fed.us/wwetac/threat-map/TRMSeed ZoneData.php (accessed Jan 2021).

Young SA, Vernon J, Shaw N. 2013. Basin wildrye (Leymus cinereus) pooled tetraploid accessions for U.S. Intermountain West rangeland reclamation. In: Michalk DL, Millar GD, Badgery WB, Broadfoot KM, editors, Proceedings of the 22nd International Grasslands Congress; Orange New South Wales (Australia): New South Wales Department of Primary Industry. p 381-382.

\section{AUTHOR INFORMATION}

\section{Scott Jensen}

Botanist

scott.I.jensen@usda.gov

Stanley Kitchen

Research Botanist

Stanley.Kitchen@usda.gov

\section{USDA US Forest Service}

Rocky Mountain Research Station SSL

735 North 500 East

Provo, UT 84606

\section{Val Jo Anderson}

Professor

val_anderson@byu.edu

\section{William Christensen}

Melvin W Carter Professor

william@stat.byu.edu

Bruce Roundy

Professor

bruceroundy4@gmail.com

Loreen Allphin

Associate Professor

loreen_allphin@byu.edu

Department of Plant and Wildlife Sciences

Brigham Young University

Provo, UT 84602 


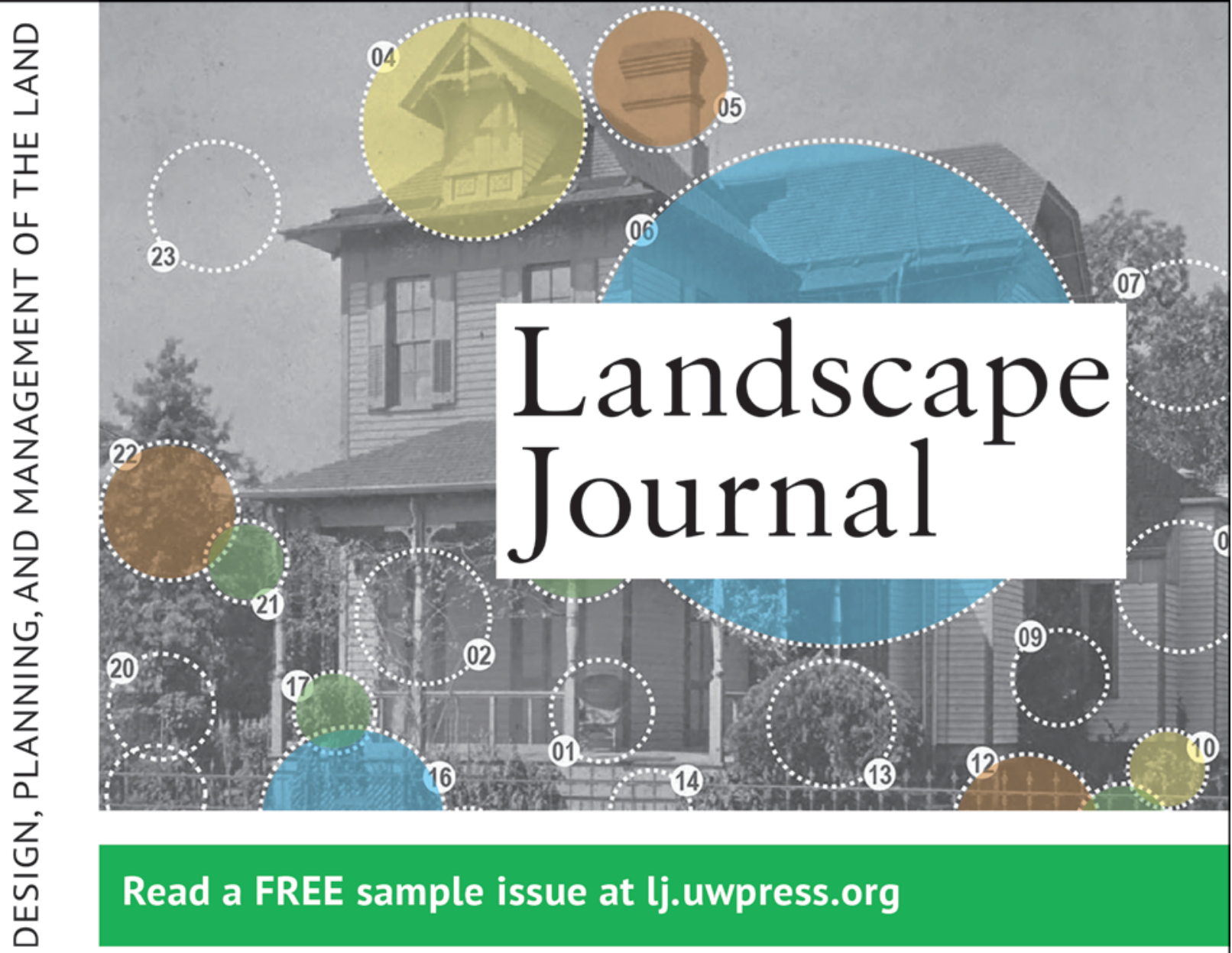

Edited by James LaGro

ISSN: 0277-2426 | e-ISSN: 1553-2704 | 2 issues/year

\section{The official journal of the Council of Educators in Landscape Architecture (CELA)}

The mission of landscape architecture is supported by research and theory in many fields. Landscape Journal offers in-depth exploration of ideas and challenges that are central to contemporary design, planning, and teaching. Besides scholarly features, Landscape Journal includes editorial columns, creative work, and reviews of books, conferences, technology, and exhibitions.

Landscape Journal digs deeper into the field by providing articles from: landscape architects $\bullet$ planners $\bullet$ ecologists $\bullet$ geographers artists $\bullet$ poets $\bullet$ architects $\bullet$ historians

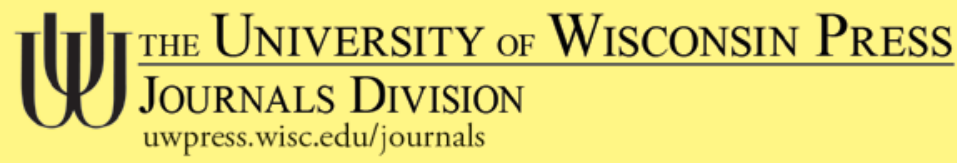

